\title{
CHALLENGES AND OPPORTUNITIES OF LOCAL FISHERIES MANAGEMENT: PIKEPERCH, SANDER LUCIOPERCA (ACTINOPTERYGII: PERCIFORMES: PERCIDAE), IN PÄRNU BAY, NORTHERN GULF OF RIGA, BALTIC SEA
}

\author{
Bärbel MÜLLER-KARULIS ${ }^{1,2 *}$, Timo ARULA ${ }^{3}$, Maija BALODE ${ }^{1}$, Kerli LAUR ${ }^{3}$, \\ and Evald OJAVEER ${ }^{3}$
}

\author{
${ }^{1}$ Latvian Institute of Aquatic Ecology, 8 Daugavgrivas, LV-1007 Riga, Latvia \\ ${ }^{2}$ Baltic Nest Institute, Stockholm Marine Centre, Stockholm University, Stockholm, Sweden (present address) \\ ${ }^{3}$ Estonian Marine Institute of the University of Tartu, 14 Mäealuse, EE-12618 Tallinn, Estonia
}
Müller-Karulis B., Arula T., Balode M., Laur K., Ojaveer E. 2013. Challenges and opportunities of local fisheries management: pikeperch, Sander lucioperca (Actinopterygii: Perciformes: Percidae), in Pärnu Bay, northern Gulf of Riga, Baltic Sea. Acta Ichthyol. Piscat. 43 (2): 151-161.

\begin{abstract}
Background. A local stock of pikeperch, Sander lucioperca (Linnaeus, 1758), is a valuable fishery resource in Pärnu Bay, northern Gulf of Riga. Due to the late maturity of pikeperch in the bay, the stock is vulnerable to overexploitation, whereas recruitment is highly dependent on climate factors. Because of its high market price, fishing pressure on the stock increased considerably in the 1990s, resulting in stock depression. To assist fishery management in Pärnu Bay we have simulated the effect of several scenarios (such as: fishing mortality, climate, and young-of-the-year food supply) on the pikeperch stock, catches, and revenues generated by the fishery.

Materials and methods. A simulation system consisting of an age-structured population model, a recruitment component, and a forcing module of different climate, food supply to young-of-the-year, and fishing mortality scenarios was used to estimate the equilibrium stock size and catches under varying environmental conditions and exploitation strategies. Economic impacts of these scenarios were assessed based on the first selling price of pikeperch.

Results. Under present climate and food supply for pikeperch young-of-the-year, the Pärnu Bay pikeperch stock is very sensitive to catches of immature fish. Warmer future climate conditions are likely to be beneficial for the stock, but also prey abundance for young-of-the-year influences potential stock sizes and catches. Compared to targeting its prey species, herring, which has a lower commercial value at current first selling prices, pikeperch acts as a "biomeliorator", roughly doubling fisheries revenue in the bay.

Conclusion. Flexible adaptive management methods should be used to estimate the yearly allowable pikeperch catch, taking into account food supply to young-of-the-year and climate conditions influencing recruitment.
\end{abstract}

Keywords: Pärnu Bay, pikeperch, temperature, year class abundance, exploitation, fishing mortality, management

\section{INTRODUCTION}

A local stock of pikeperch, Sander lucioperca (Linnaeus, 1758), adapted to brackish water conditions, is a valuable fishery resource in Pärnu Bay (Vetemaa et al. 2000, 2006), a shallow bay in the Estonian exclusive economic zone in the Northern Gulf of Riga (Fig. 1). Despite fishing regulations, which were established in Estonia as early as in the 1920s, this stock has been heavily exploited since the early 1930s, when large-scale export of this fish from Estonia started. After low catches in the 1960s new, biologically justified measures to protect pikeperch were implemented, such as protected areas and the use of artificial spawning substrates to increase recruitment. Catches then improved and reached $300 \mathrm{t}$ in the early 1990s (Erm et al. 2003).
After Estonia regained independence in 1991, new export markets for pikeperch opened and privatization of state farms offered local fishermen cheap access to fishing gear. With Estonia's low average wages in the early 1990s and high first-buyer prices for pikeperch, the average catch of pikeperch needed to provide the equivalent of an average monthly gross wage ranged from $43 \mathrm{~kg}$ in 1993 to $240 \mathrm{~kg}$ in 1999 (Vetemaa et al. 2000, 2006). Consequently, pikeperch catches increased drastically and its fishing mortality rose to the highest level ever recorded. Young age groups, including immature fish, became an important part of the catches. This was caused by Estonia's weak legal instruments for regulating fisheries in the 1990s (Vetemaa et al. 2002) and by insufficient funding for enforcing the legal minimum size of

\footnotetext{
${ }^{*}$ Correspondence: Dr Bärbel Müller-Karulis, Stockholms universitets Östersjöcentrum, Stockholms universitet, SE-106 91 Stockholm, Sweden, phone: +4686747574 ,
} fax: +4681637 18, e-mail: barbel.muller.karulis@su.se. 
pikeperch in catches (Eero 2004). Pikeperch reach full maturity only at the age of 5 years, with females maturing later (4-5 years) than males (3-4 years), which makes the stock sensitive to harvesting of immature fish (Erm et al. 2003). Because fishermen in the 1990s to a large extent targeted young age groups before the end of their most rapid growth period, the profits of this fishery were much smaller than would have been in the case of sustainable management. After 1997 landings decreased sharply (Eero 2004) and the fishery was temporarily closed in 2000-2003.

Recruitment success determines the internal dynamics of the Pärnu Bay pikeperch stock (Eero 2004). The shallow bay (mean depth $5 \mathrm{~m}$ ) covers about $700 \mathrm{~km}^{2}$ and its salinity ranges from PSU 1 through 5 (Kotta et al. 2009 and references therein). The climate is rather continental, with ice covering the bay in winter and the water temperature rising to $24^{\circ} \mathrm{C}$ in summer (Arula et al. 2012). Pikeperch spawns on sandy bottoms in May and June (Erm et al. 2003). The larvae are planktivorous, first consuming nauplii and young stages of Eurytemora affinis and Acartia bifilosa (Copepoda). At the end of July young-of-the-year (YOY) pikeperch become piscivorous, at first preying chiefly on goby (Pomatoschistus spp.) larvae as well as Neomysis sp. and Corophium sp., and later mainly on juvenile gobies (Erm 1981a).

Strong year classes of pikeperch are produced when spawning coincides with warm water and calm weather (Erm 1981a, b). Further, abundant food, especially goby larvae and juvenile gobies, when the early juveniles switch to piscivory improves the growth and consequently survival during the following winter (Lappalainen et al. 2000). The wintering conditions for the 0-group pikeperch, including winter severity, ice cover duration, abundance of predators, and fishing intensity in Pärnu Bay, constitute the final bottleneck for recruitment to the stock (Lappalainen et al. 2002).

In addition to climatic fluctuations, eutrophication is a major driving force of ecosystem changes in Pärnu Bay and the adjacent Gulf of Riga. In the small, shallow and comparatively isolated Gulf of Riga surrounded by agricultural land and industrial centres, eutrophication became evident earlier and was more pronounced than in the open Baltic Sea. Eutrophication increased rapidly from the 1960s through the 1980s, had a peak in the late 1980s, and decreased slightly in the 1990s (Nehring et al. 1989, Berzinsh 1995, Anonymous 1996, 2002). However, pikeperch is well known to tolerate or even benefit from eutrophication in freshwater systems (Garcia et al. 2006, Kangur et al. 2007) and Baltic coastal waters (Lehtonen et al. 1996, Lappalainen et al. 2002, Sandström and Karås 2002). Therefore eutrophication most likely poses no direct threat to pikeperch in Pärnu Bay.

Being the largest predator in the Pärnu Bay ecosystem, pikeperch converts the biomass of commercially unexploited fish-gobies (Pomatoschistus spp.); bleak, Alburnus alburnus (L., 1758); sticklebacks, Gasterosteus aculeatus L., 1758; roach, Rutilus rutilus (L.; 1758) - and species of moderate value as herring, Clupea harengus L., 1758; and smelt, Osmerus eperlanus (L., 1758), into biomass of high commercial value and acts thus as a "biomeliorator". Therefore, sustainable management of pikeperch resources is of high importance for the coastal population around Pärnu Bay. To identify potential management strategies for the Pärnu Bay pikeperch population we have developed scenario simulations that address different exploitation rates, weak or strict enforcement of the legal size limit, varying prey availability to young-of-the-year, and the effect of climate change on the stock dynamics.

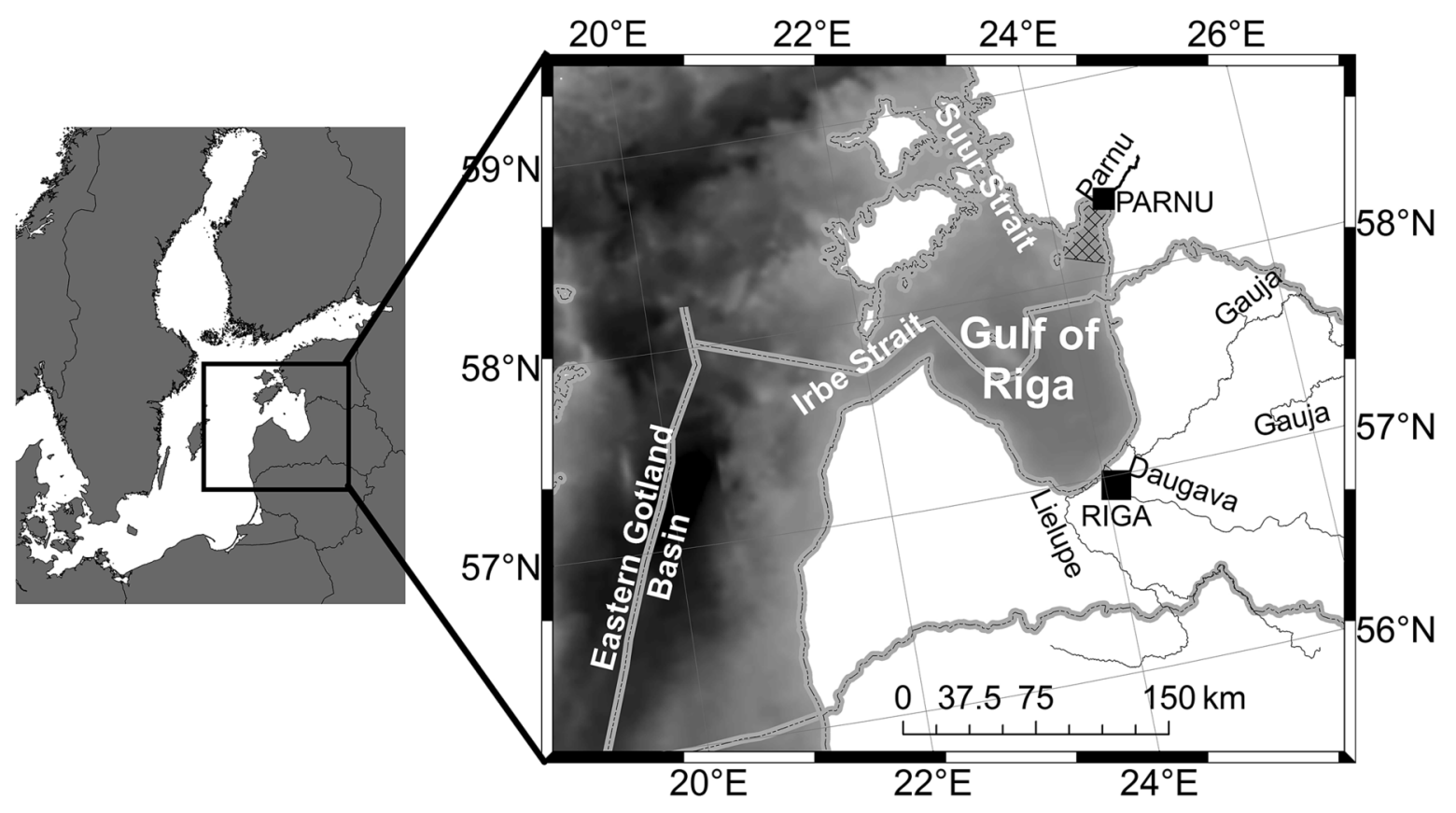

Fig. 1. Location of Pärnu Bay (crosshatched area) in the northern part of the Gulf of Riga, Baltic Sea 


\section{MATERIALS AND METHODS}

To estimate stock sizes and catches of Pärnu Bay pikeperch in equilibrium with different management strategies, exploitation rates, as well as climate and prey abundance scenarios, we have designed a simulation system with an age-structured population model for the pikeperch stock, driven by fishing mortality $(F)$ and environmentally dependent recruitment, as core component. The population model was forced by fishing mortality in combination with artificial time series capturing expected climate change and different levels of food supply to young-of-the-year pikeperch.

Pikeperch population model. The population model follows a standard Virtual Population Analysis (VPA) model with a Baranov catch equation (Haddon 2011) and describes the population dynamics of Pärnu Bay pikeperch using 10 age classes as in Eero (2004). The number of fish in age class $i$ at the beginning of year $j+1$, $N_{i}^{j+1}$, is calculated as:

$$
N_{i}^{j+1}=N_{i-1}^{j} \exp \left(-M_{i-1}^{j}-F_{i-1}^{j}\right)
$$

where $M_{i-1}^{j}$ denotes the natural mortality of age group $i$ experienced during the previous year, while $F_{i-1}^{j}$ describes the fishing mortality incurred. Age class 10 survivors were returned to age class 10 at the end of each year to close the population model.

Integration in time then gives the annual catch weight in age class $i, C_{i}^{j}$, as

$$
C_{i}^{j}=N_{i}^{j} w_{i}^{j}\left(1-\exp \left(-F_{i}^{j}-M_{i}^{j}\right)\right) \frac{F_{i}^{j}}{F_{i}^{j}+M_{i}^{j}}
$$

where $w_{i}^{j}$ is the weight at age $i$ during year $j$. In our simulations, we used a constant average weight (Eero 2004) for each age-class of pikeperch.

Stock-recruitment component. We used a generalized additive model (Hastie and Tibshirani 1986, Wood 2006) implemented in the R software package (www.R-project.org) to fit the recruitment success of Pärnu Bay pikeperch to a Ricker-type stock recruitment relation modified by environmental factors:

$\log \frac{N_{1}^{j}}{S S B^{j-1}}=a+b \cdot S S B^{j-1}+c \cdot \log \left(G^{j-1}\right)+s\left(T^{j-1}\right)+s\left(I^{j-1}\right)[3]$ where $N_{1}^{j}$ is the number of one-year olds at the beginning of year $j$, and factors indexed by $j-1$ refer to conditions during the previous year. $G^{j-1}$ is a trawl index for juvenile and larval gobies (from here on: gobies) in Pärnu Bay proportional to the median of goby abundance determined by weekly Hensen trawls above the thermocline during May-July (Ojaveer et al. 2011, Arula et al. 2012). $T^{j-1}$ refers to the average May-July air temperature in Pärnu during the year the recruits where spawned, while $j^{-1}$ is the ice duration in Pärnu Bay during their first winter; $a$, $b$, and $c$ are model coefficients, while $s()$ denotes nonparametric spline functions. These parameters were selected over a number of other proxies (NAO, winter air temperature, summer water temperature, salinity, Secchi depth, zooplankton- and mysid abundance) for climatic and feeding conditions in Pärnu Bay to achieve a simple model with large $R^{2}$ and low AIC (Akaike 1974). Using output from a 1960-1998 virtual population analysis of the Pärnu Bay pikeperch stock (Eero 2004) as calibration data, the final model explained $63.5 \%$ of the data deviance $\left(R_{\text {adj }}^{2}=0.48\right)$. All four variables contributed notably to the explanatory power of the model and were significant at $0.02<P \leq 0.10$. Compared to models using only three explanatory variables, each variable improved the explained deviance by 15.1 percentage points (goby abundance) through 27 percentage points (summer temperature).

The output of the stock-recruitment component was corrected for the bias introduced by the log transformation (Sprugel 1983) of the recruitment success data. Bias correction was based on the standard error of the model estimates and the approximate degrees of freedom of the GAM model. Further, we have added noise to the output of the recruitment model to ensure that average and standard deviation of the simulated recruitment corresponded closely to the mean and standard deviation of the available calibration data. The noise component was normally distributed with a mean of zero and standard deviation corresponding to the average prediction standard error estimated by the original GAM stock-recruitment model. Population and recruitment component coupling. Spawning stock biomass (SSB) links recruitment and pikeperch stock dynamics. Spawning stock biomass $\mathrm{SSB}^{j}$ at the beginning of year $j$, is calculated as

$$
S S B^{j}=\sum_{i=0}^{10} m_{i}^{j} w_{i}^{j} N_{i}^{j}
$$

where $m_{i}^{j}$ is maturity at age $i$ during year $j$. Both maturity and weight at age were assumed constant with values taken from Eero (2004).

Dynamic simulations. Dynamic simulations of the pikeperch population model were implemented using ExtendSim (www.extendsim.com) software. The population model was initialized by the observed 1980 pikeperch stock (Eero 2004) and then run to equilibrium, i.e., until stock size and catches showed no further temporal trend, forced by constant fishing mortality in combination with fluctuating climate and prey abundance time-series. The last 100 years of each simulation run were then used to derive average stock characteristics (total biomass, SSB, number of recruits) and the magnitude of catches, together with their $5 \%$ and $95 \%$ percentiles to indicate the magnitude of stock and catch fluctuations. The spin-up period was set arbitrarily to 2000 years to ensure that the stock was at equilibrium with the climatic forcing and applied fishing mortality.

Management scenarios. The fishing mortality experienced by the Pärnu Bay pikeperch population during the time-period covered by VPA data fluctuated between 0.5 and 2.25 (average 0.89) for mature fish (ages 5-10+), and between 0 and 0.75 (average 0.08 ) for the partially mature ages 3 and 4 (Eero 2004). Comparing the time period before (1960-1989) and after (1993-1998) the breakup of the Soviet Union (Table 1), fishing mortality increased 2.5-fold for mature fish and the fishing mortality of partially mature fish rose from zero to about one tenth (age 3) and one third (age 4) of the fishing mortality experienced by 5-year olds. 
Based on these fishing patterns, we constructed two contrasting management scenarios: a) assuming a strict enforcement of the legal size limit for pikeperch $(44 \mathrm{~cm})$ and consequently no catch of immature fish (ages 3-4) and b) significant catch of undersized, immature pikeperch. For scenario a), selectivity, i.e., the ratio of fishing mortality for each age group to total fishing mortality was kept at average values observed in 1960-1989. In scenario b) the fishing mortality of ages 3 and 4 was set to $10 \%$ and $33 \%$ of the fishing mortality experienced by 5 -year old fish, corresponding roughly to the pattern observed in 1993-1998. For older fish, selectivity corresponded to the 1960-1989 average, giving both management scenarios equal fishing mortality for mature fish.

Climate and prey abundance scenarios. Climate scenarios were based on a) a baseline climate, which captured the statistical characteristics of the observed climate used to calibrate the stock-recruitment model for Pärnu Bay pikeperch (Table 2), and b) a future climate scenario, where temperature and ice cover duration were shifted to mimic the effects of assumed global warming.

To construct forcing time series with sufficient length to analyse equilibrium conditions between pikeperch stock and the applied fishing pressure, we first checked the input time series-temperature, ice cover duration, and goby abundance-for autocorrelation. Because all autocorrelation functions were small, forcing time series were generated by a normally distributed random variable preserving the mean and standard deviation of the input data. For goby abundance and ice cover transformed data were used to ensure that forcing functions mimicked the distribution of the original variables.

According to bias-corrected results of regional climate models the predicted air temperature increase based on the Intergovernmental Panel on Climate Change (IPCC) A2 emission scenario in the Gulf of Riga is about $3.5^{\circ} \mathrm{C}$ until 2070-2100. In this case at least the central areas of the basin will be ice free in winter (Sennikovs and Bethers unpublished*). Because the magnitude of expected climate change within this time period is larger than the temperature and ice cover range covered by the input data for the stock recruitment model (Table 2), we have constructed a hypothetical intermediate future climate scenario by adding a moderate increase $\left(1.5^{\circ} \mathrm{C}\right)$ to the baseline temperature time series, setting the ice cover duration simultaneously to the observed minimum (67 days). Temperatures in the future climate scenario exceeding the range covered by the recruitment model input (about $25 \%$ of the simulated future temperatures) were capped at the observed maximum $\left(17.1^{\circ} \mathrm{C}\right)$.

To mimic the effect of prey abundance to YOY pikeperch on the pikeperch stock and the fisheries, a low food availability scenario was generated by setting the abundance of gobies to its $5 \%$ percentile (trawl index $=22$ ). In a contrasting, high prey scenario the goby abundance was set to its $95 \%$ percentile (trawl index $=240$ ).

Fishery management scenarios. Stakeholder consultations in meetings with representatives of the Estonian
Ministry of the Environment (Fisheries Division), Estonian Ministry of Agriculture, fishermen's organizations, nature conservation bodies, and a group of marine scientists in both Estonia and Latvia suggested that exploitation of the Pärnu Bay pikeperch stock should gradually be adjusted so that mortalities corresponded to a sustainable optimum management of the stock, corresponding to its maximum sustainable yield (MSY). The economic implications of managing Pärnu Bay pikeperch at maximum sustainable yield were therefore estimated for each fishing mortality setting, prey abundance to YOY and climate scenario by calculating the revenue generated at first sale of pikeperch, based on the first price of $€ 5.0 \cdot \mathrm{kg}^{-1}$ reported by the stakeholders ( $€=$ euro). Further, we compared this estimate to the potential revenue from fishing herring, which is the major pikeperch prey. The potential revenue from fishing the annual herring consumption of the

Table 1

Fishing mortalities experienced by the Pärnu Bay pikeperch (Sander lucioperca) stock before(1960-1989) and after (1993-1998) the breakup of the Soviet Union, calculated from Eero (2004)

\begin{tabular}{lll}
\hline \multirow{2}{*}{ Age } & \multicolumn{2}{c}{ Fishing mortality } \\
\cline { 2 - 3 } & $1960-1989$ & $1993-1998$ \\
\hline 1 & $0.00 \pm 0.00$ & $0.00 \pm 0.00$ \\
3 & $0.00 \pm 0.00$ & $0.00 \pm 0.00$ \\
4 & $0.00 \pm 0.00$ & $0.24 \pm 0.15$ \\
5 & $0.01 \pm 0.01$ & $0.75 \pm 0.36$ \\
6 & $0.47 \pm 0.23$ & $2.04 \pm 0.79$ \\
7 & $0.81 \pm 0.39$ & $1.98 \pm 0.65$ \\
8 & $0.80 \pm 0.30$ & $1.63 \pm 0.45$ \\
9 & $0.87 \pm 0.38$ & $1.86 \pm 0.11$ \\
$10+$ & $0.68 \pm 0.00$ & $1.70 \pm 0.50$ \\
\hline $3-4$ & $0.68 \pm 0.00$ & $1.70 \pm 0.50$ \\
\hline $5-10+$ & $0.00 \pm 0.00$ & $0.50 \pm 0.23$ \\
\hline Values are & $0.72 \pm 0.16$ & $1.82 \pm 0.36$ \\
\hline
\end{tabular}

Values are mean \pm standard deviation.

Table 2

Baseline climate- and prey

abundance scenario data (1960-2008) in Pärnu Bay

\begin{tabular}{lccc}
\hline & $\begin{array}{c}\text { Goby } \\
\text { abundance } \\
\text { [trawl index }]\end{array}$ & $\begin{array}{c}\text { Summer air } \\
\text { temperature } \\
{\left[{ }^{\circ} \mathrm{C}\right]}\end{array}$ & $\begin{array}{c}\text { Ice cover } \\
\text { duration } \\
{[\text { days] }}\end{array}$ \\
\hline Average & 54.6 & 14.7 & 130 \\
Min & 3.00 & 12.4 & 67 \\
Max & 306 & 17.1 & 164 \\
Standard deviation & 60.9 & 0.98 & 24.1 \\
Transformation & Log & none & cubic \\
\hline
\end{tabular}

Transformation $=$ transformation to approximate normal distribution; Goby $=$ Pomatoschistus spp.

\footnotetext{
${ }^{*}$ Sennikovs J., Bethers U. 2009. Statistical downscaling method of regional climate model results for hydrological modelling, 18th World IMACS / MODSIM Congress, Cairns, Australia.
} 
pikeperch stock was based on a first price of $€ 0.15 \cdot \mathrm{kg}^{-1}$ for herring, an annual consumption rate of 6.0 times the total stock biomass, similar to Pärnu Bay piscivore consumption in Tomczak et al. (2009), and an $80 \%$ share of herring in the pikeperch diet (Ojaveer et al. 1997).

\section{RESULTS}

Model performance. The simulation system (equations 1-4) implemented in ExtendSim was validated in two steps, using as reference dataset the VPA estimates of Eero (2004), which the author kindly made available as number of fish in age classes 1-10 covering 1960-1998. First, we validated the recruitment component by initializing the stock to its 1960 VPA estimate and then forcing the model with the VPA estimates of SSB and the observed temperature, ice cover and goby abundance data used in calibrating the stock-recruitment model (Fig. 2, left). Next, we fully coupled recruitment and population model components by using modelled SSB as input to the recruitment component, simulating changes in the stock in 1960-1995 forced now only by the VPA estimates of fishing mortality and the observed environmental conditions for recruitment (Fig. 2, right). Gaps in the environmental forcing were replaced by averages in the coupled model validation, while the corresponding years were omitted in the recruitment component validation and are consequently not shown in Fig. 2 (right). Confidence intervals were generated as the $5 \%$ and $95 \%$ percentiles of 1000 simulated stock trajectories.

The recruitment component of the model gives a fair description of observed recruitment (Fig. 2, left). The model reflects the high recruitment observed in the 1960s and around 1990 and corresponds closely to the intermediate recruitment levels observed during the 1980s. However, the model overestimates the low reproduction of the stock observed in the late 1970s and while observed SSB declined in the late 1970s and the early 1980s, the overestimated recruitment caused a pronounced increase in the stock. During these years goby abundance in Pärnu Bay was low. This indicates that the stock-recruitment model does not fully capture the impact of poor prey availability, which had a pronounced effect on the simulated stock during this period, since fishing mortality simultaneously was at its lowest observed level.

Effect of harvesting immature fish. Under present climate conditions and current food supply to YOY, the Pärnu Bay pikeperch stock is very sensitive to catches of the age groups 3 and 4 at high exploitation rates (Fig. 3). While at low to moderate fishing mortality $\left(F_{5-10}<0.8\right)$ both exploitation patterns reach similar SSB and catches, at higher exploitation rate harvesting immature fish decreases the SSB and has an even more pronounced effect on equilibrium catches. Even at the high exploitation rates for mature fish observed after the break-up of the Soviet Union $\left(F_{5-10}=1.82\right)$ the stock could still have sustained a catch of $138 \mathrm{t}$ annually, had there been no catch of immature fish, compared to a simulated $38 \mathrm{t}$ with such catches.

The simulated SSB and catch curves further indicate that during the Soviet collective fishery management period exploitation rates were mostly at equilibrium with stock dynamics. VPA estimated SSB and catches mostly fall within the 5\%-95\% confidence interval of their simulated equilibrium values. Only during 1968-1971 did catches significantly exceed the equilibrium range, fishing down the strong year-classes spawned in the early 1960s which lead to a subsequent drop in SSB (Fig. 2, see also Eero 2004).

Post-soviet exploitation rates mostly exceeded equilibrium catches, even assuming a strict enforcement of the legal size limit (Fig. 3, top right). Targeting also immature fish, catches greatly exceeded their equilibrium values (Fig. 3, bottom right), causing a rapid stock decline.

Pikeperch stock dependence on food supply to youngof-the-year. Setting the prey abundance to YOY pikeperch to bottom and top 5\% of observed values had a clear effect on equilibrium SSB and catches (Fig. 4). At low goby abundance SSB and catches declined, while high prey abundance led to a pronounced rise in sustainable harvest and corresponding stock size. Simultaneously the prediction confidence interval became larger, suggesting that at large stock size equilibrium SSB and annual catch
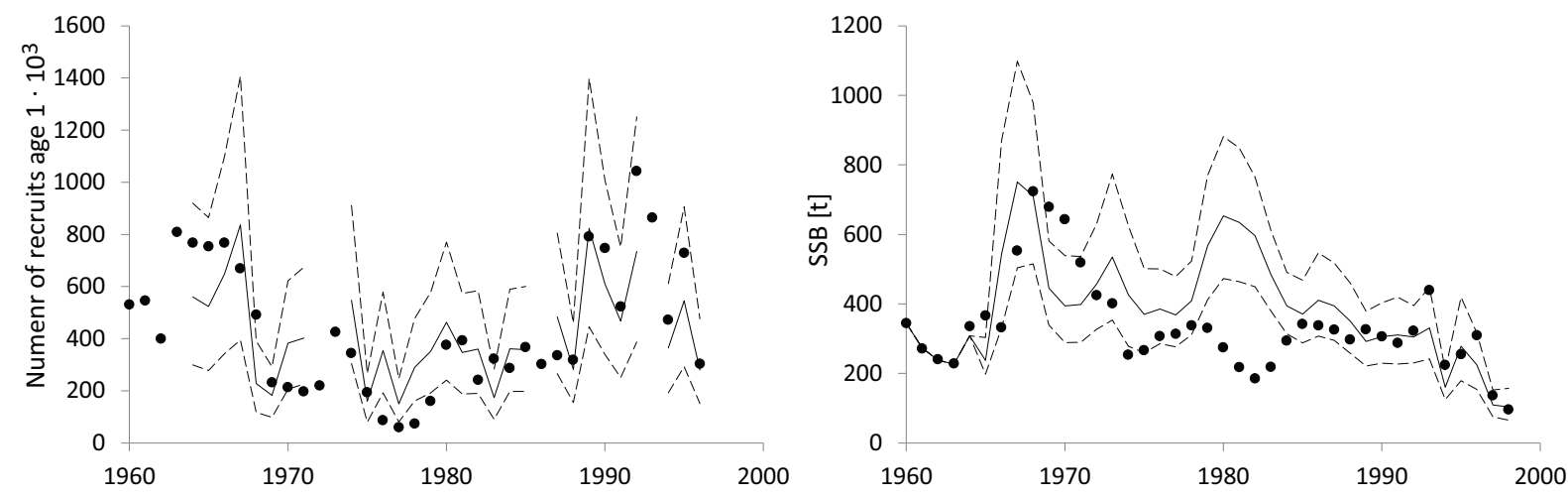

Fig. 2. Number of recruits at age 1 (left) and spawning stock biomass (right) simulated by the pikeperch (Sander lucioperca) population model (lines: model results (continuous) with 5\% and 95\% percentiles (dashed), dots: VPA estimates (Eero 2004, Eero, personal communication) 
will fluctuate more. In the model, the increased fluctuations at high stock size are produced by the exponential functions applied in the catch equation (Equation 2) and in the stock-recruitment function (Equation 3).

Impact of expected climate change. Expected climate change has an even larger positive effect on equilibrium SSB than high goby abundance. Our simulations indicate that the stock might sustain catches of close to $500 \mathrm{t}$ annually at a SSB of about $800 \mathrm{t}$ (Fig. 5).
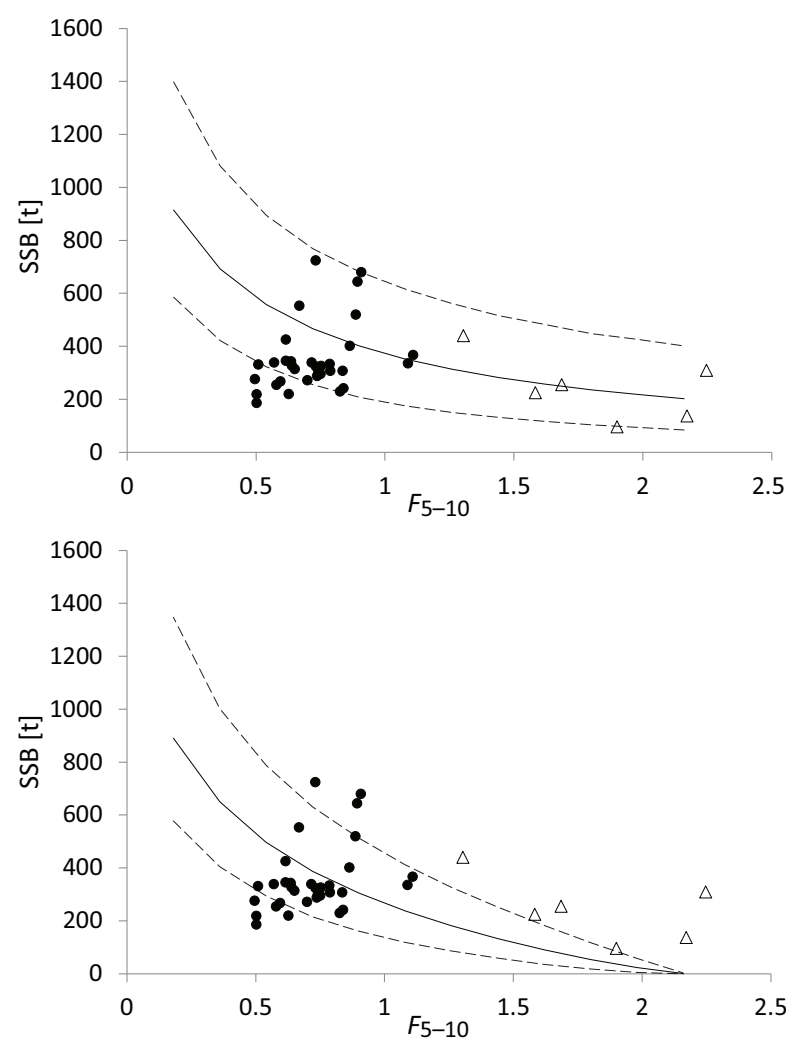

Revenue generated at maximum catch. Under our first selling price assumptions, the annual revenue generated by harvesting pikeperch at maximum equilibrium catch rates varies from $€ 614000$ per year under unfavourable YOY feeding conditions to $€ 2474000$ per year in a potential warmer climate (Table 3 ). Significant catches of immature fish decrease the annual revenue by approximately $14 \%$ from $€ 814000$ per year to $€ 704000$ per year, assuming the fishing mortality can be maintained at
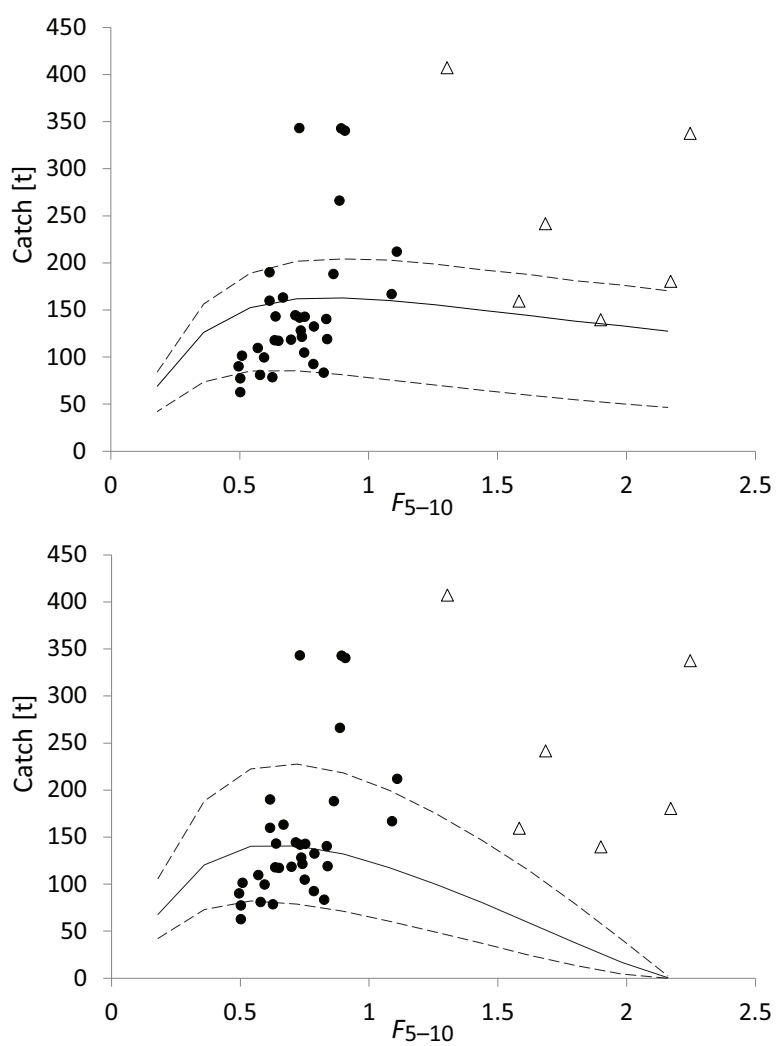

Fig. 3. Spawning stock biomass (left) and catch (right) in equilibrium with different levels of fishing mortality, assuming no (top) or significant catch (bottom) of immature, undersized pikepearch (Sander lucioperca); Lines show average simulated SSB and catch (continuous), with 5\% and 95\% percentiles (dashed); Markers denote observed SSB and catches (Eero 2004) with no (circles) or significant (triangles) catch of immature fish; $F_{5-10}=$ average fishing mortality age 5-10

Table 3

Fishing mortality, annual catch, equilibrium total stock biomass and revenue generated at maximum catch of pikeperch (Sander lucioperca) for simulated scenarios, compared to potential revenue generated from harvesting equivalent herring prey

\begin{tabular}{lcccccc}
\hline Scenario & $\begin{array}{c}\text { Fishing } \\
\text { mortality }\end{array}$ & $\begin{array}{c}\text { Catch } \\
{[\mathrm{t} \cdot \text { year }}\end{array}$ & $\begin{array}{c}\text { Total stock } \\
(\mathrm{SSB} \text { in brackets }) \\
{[\mathrm{t}]}\end{array}$ & $\begin{array}{c}\text { Annual herring } \\
\text { consumption } \\
{\left[\mathrm{t} \cdot \mathrm{year}^{-1}\right]}\end{array}$ & $\begin{array}{c}\text { Pikeperch } \\
\text { revenue } \\
{\left[\mathrm{k} € \cdot \mathrm{year}^{-1}\right]}\end{array}$ & $\begin{array}{c}\text { Equivalent } \\
\text { herring revenue } \\
{\left[\mathrm{k} € \cdot \text { year }^{-1}\right]}\end{array}$ \\
\hline PCPANIP & 0.9 & 163 & $582(401)$ & 2794 & 814 & 419 \\
PCPASIP & 0.54 & 140 & $677(497)$ & 3249 & 701 & 487 \\
PCLPANIP & 0.72 & 123 & $491(353)$ & 2357 & 614 & 353 \\
PCHPANIP & $>2.16$ & 338 & $912(536)$ & 4378 & 1690 & 657 \\
FCPPANIP & $>2.16$ & 495 & $1354(787)$ & 6500 & 2474 & 975 \\
\hline
\end{tabular}

$\mathrm{k} €=$ thousands of euro; PCPANIP = Present climate and prey abundance to YOY, no catch of immature pikeperch; PCPASIP = Present climate and prey abundance to YOY, significant catch of immature fish; PCLPANIP =Present climate, low prey abundance to YOY, no catch of immature pikeperch; PCHPANIP =Present climate, high prey abundance to YOY, no catch of immature pikeperch; FCPPANIP = "Future" climate, present prey abundance to YOY, no catch of immature pikeperch. SSB = spawning stock biomass. 
its low equilibrium value. Compared to targeting herring, fishing pikeperch was economically beneficial in all scenarios and approximately doubled the revenue generated. Targeting pikeperch was particularly advantageous in scenarios with good pikeperch reproduction conditions (no catch of immature pikeperch, high prey abundance to YOY, future climate), because high recruitment increases the yield per stock biomass and consequently generates higher yield for each unit of herring consumed by pikeperch.

\section{DISCUSSION}

The stock-recruitment model constructed for the Pärnu Bay pikeperch population confirms the importance of water temperature, winter severity, and abundance of goby for recruitment found by earlier analysis of longterm monitoring data (Erm 1981a, b, Lappalainen et al. 2000). In addition, it predicts a decline of recruitment success at high SSB (coefficient $b<0$ in equation 3 ). In the modelled scenarios, this effect stabilizes the equilibrium SSB and catch curves at large fishing pressure, because the smaller SSB is partly offset by a larger number of recruits per spawner, creating the slowly tailing catch-curves in scenarios describing beneficial recruitment conditions (expected climate change, high goby abundance). A similar weak negative relation between pikeperch spawning stock biomass and recruitment success was found in coastal areas of the Southern Baltic (Gröger et al. 2007), most likely caused by cannibalism at high number of recruits (Winkler 1989). Pikeperch cannibalism is also well known from lakes, especially at high juvenile density (Frankiewicz et al. 1999, Lappalainen et al. 2006), but has so far not been documented in Pärnu Bay. Intraspecific competition between juveniles in strong yearclasses has also been suggested to make pikeperch recruitment density-dependent (Lappalainen et al. 2009).

Incorporating environmental variables can enhance the performance of stock-recruitment models (Fiksen and Slotte 2002, Marjomäki 2004, Keyl and Wolff 2008) and GAM models are a flexible tool for incorporating non-linear environmental effects (Daskalov 1999, Chen et al. 2005, Megrey et al. 2005, Keyl and Wolff 2008). Even though the pikeperch stock-recruitment model presented here performs well, with most data points within the $95 \%$ confidence limit of the model (Fig. 2), overestimated reproduction during consecutive years in the late 1970s gave a pronounced deviation between observed and simulated SSB in the early 1980s, resembling the ordinary error amplification effect in stepwise models (Håkanson 1999, 2003).

In all modelled scenarios, the variability in predicted catches is largest at high fishing mortality, good overall recruitment conditions (high goby abundance, climate change), and stock sizes, when the stock removal through
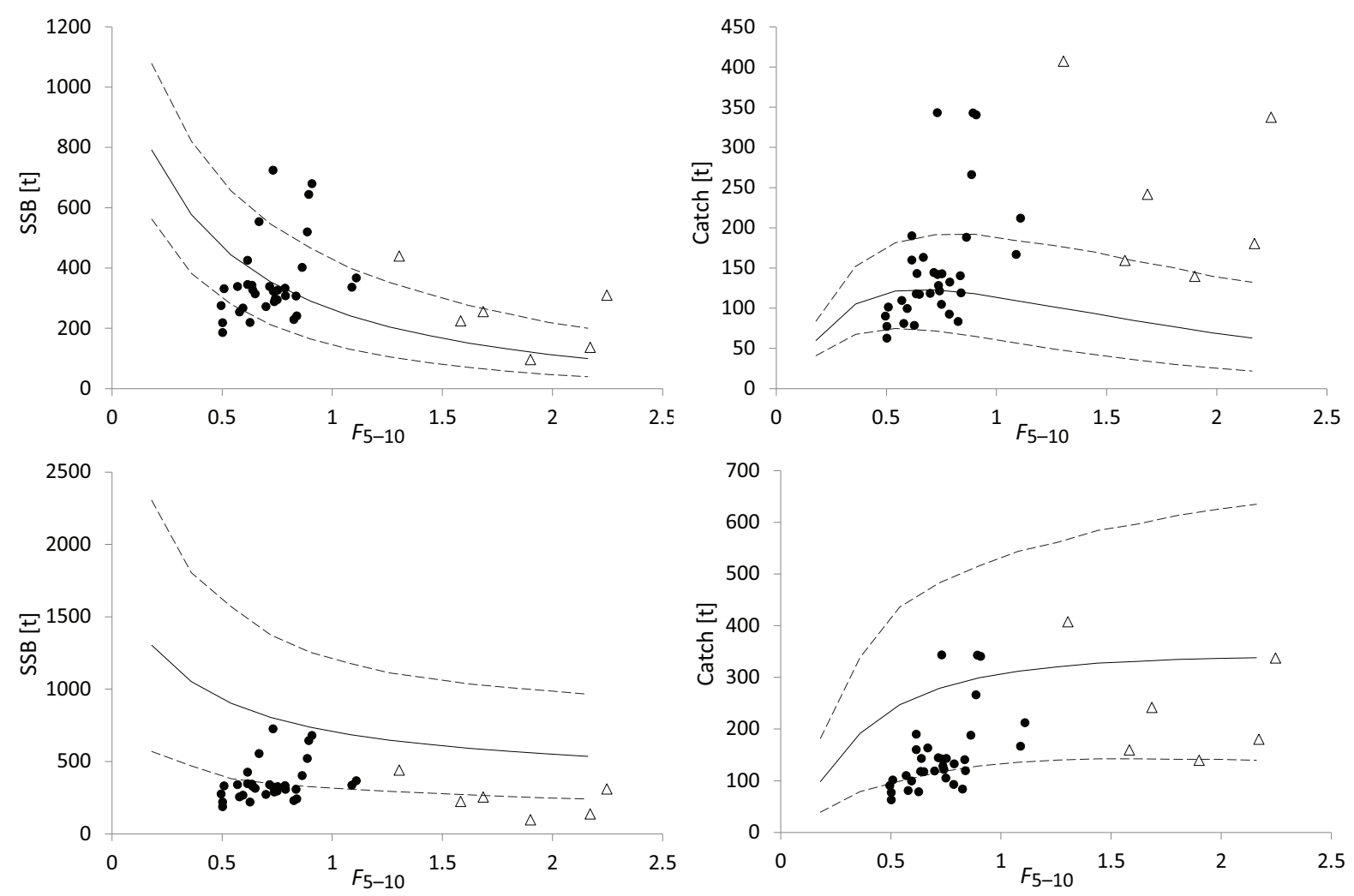

Fig. 4. Selected population characteristics of the Pärnu Bay pikepearch (Sander lucioperca): Spawning stock biomass (left) and catch (right) in equilibrium with different levels of fishing mortality, assuming low (top) or high (bottom) food supply expressed as goby abundance; Lines show average simulated SSB and catch (continuous), with 5\% and 95\% percentiles (dashed). Markers denote observed SSB and catches (Eero 2004) with no (circles) and significant (triangles) catch of immature fish; $F_{5-10}=$ average fishing mortality age 5-10 
catches is roughly balanced by a gain in recruitment success. Similar density-dependent effects have been shown to contribute to fluctuations in "Norwegian" cod (Bjørnstad et al. 1999) and marine crab populations (Higgins et al. 1997). Moreover, in our scenarios this effect is amplified by high fishing pressure, which immediately removes strong year-classes from the stock when the fish reach the legal size limit. Theoretical analysis of age-structured models has shown variability to increase with exploitation rate, reproductive success, and maturation age of the population (Andrews et al. 2004). This effect has also been found in empirical studies of North Sea cod (Andrews et al. 2004) and marine crabs (Higgins et al. 1997).

Our scenarios indicate a positive effect of the expected climate change towards higher temperatures on the pikeperch stock. However, the average simulated stock size at $F_{5-10}=1$ is about $1000 \mathrm{t}$, fluctuating between 300 and $1800 \mathrm{t}$ (5\% and $95 \%$ percentiles). The maximum stock size used to construct the stock-recruitment model was $720 \mathrm{t}$, implying that a large part of the stock sizes simulated in scenarios beneficial to pikeperch reproduction (high goby abundance, expected climate change) are outside the range for which the stock-recruitment relation has been calibrated. Lappalainen et al. (2009) have suggested that density dependent effects on recruitment might increase in a warmer climate, making the effect of climate change on pikeperch populations more complex. Further, our model does not take into account whether Pärnu Bay can provide enough food for a doubled or tripled pikeperch population. A recent food web model (Tomczak et al. 2009) indicates that in Pärnu Bay piscivores, especially the quantitatively dominating perch, exert the strongest top-down control on planktivores within the five coastal ecosystems studied. This suggests that food competition will play a role if there is a large increase in piscivorous fish populations. In a warmer future climate, also some assumptions underlying our model might no longer hold. Higher temperatures can be expected to increase the growth rates of many fish species in the Baltic (MacKenzie et al. 2007 and reference therein),

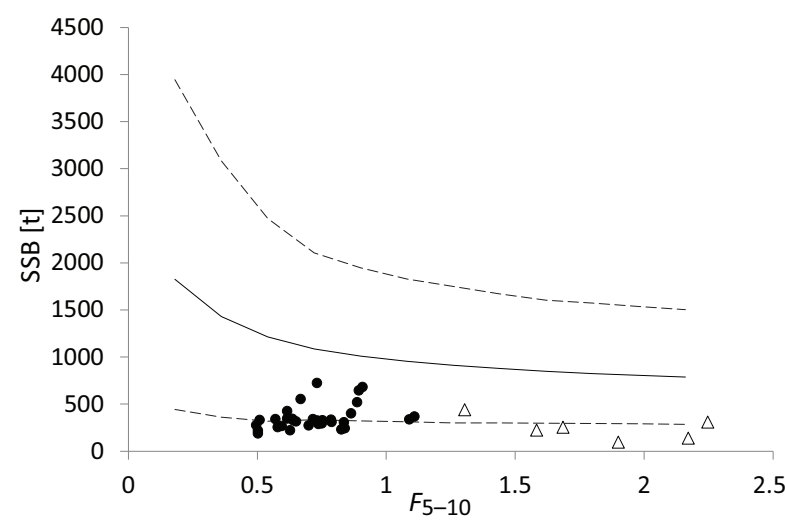

implying a change in weight at age. Faster growth in turn causes earlier maturity in pikeperch populations adapted to warmer conditions (Lappalainen et al. 2003). Therefore the Pärnu Bay pikeperch stock might be less sensitive to the catch of small fish in a future warmer climate.

Goby abundance in Pärnu Bay has declined since the 1960s (Laur et al. 2009) and is mainly related to low water transparency (Laur et al. unpublished*), which in turn depends on wind-induced resuspension, ship traffic, and peat processing in the shallow bay (Paavel et al. 2011). Many fish larvae feeding on zooplankton depend on vision in their search for prey (Guthrie 1986) and therefore increased turbidity of the water can reduce feeding and reaction distance. On the other hand, suspended particles interfere with detection by predators (Utne-Palm 2002). Pikeperch has a "spying" feeding behaviour and is favoured by low water transparency (Erm 1981b and references therein). Thus, the interactions between goby abundance, turbidity and prey abundance for YOY pikeperch are complex, which is also expressed by the relatively low contribution of goby abundance to the explained deviance in the stock-recruitment model and by the underestimation of recruitment during low goby abundance.

Our estimates of the pikeperch fishery revenue in comparison to targeting their main prey species, herring, clearly indicate that pikeperch acts as a "biomeliorator" in Pärnu Bay. However, these estimates are sensitive to the first selling price of both pikeperch and herring. According to the stakeholder consultations fishermen and fishing companies perceive a high market demand for pikeperch and expect high prices also in the future. Therefore stakeholders preferred to introduce a sustainable optimum management scheme by adjusting the pikeperch fishing mortality to maximize the catch from the stock. To achieve this goal, the following measures were suggested: 1) the mortality of immature pikeperch should be reduced considerably. Combined methods should be applied to limit catches (temporal/spatial closures, limitations by gear types or by professional/nonprofessional fishermen) 2) allowable annual catches

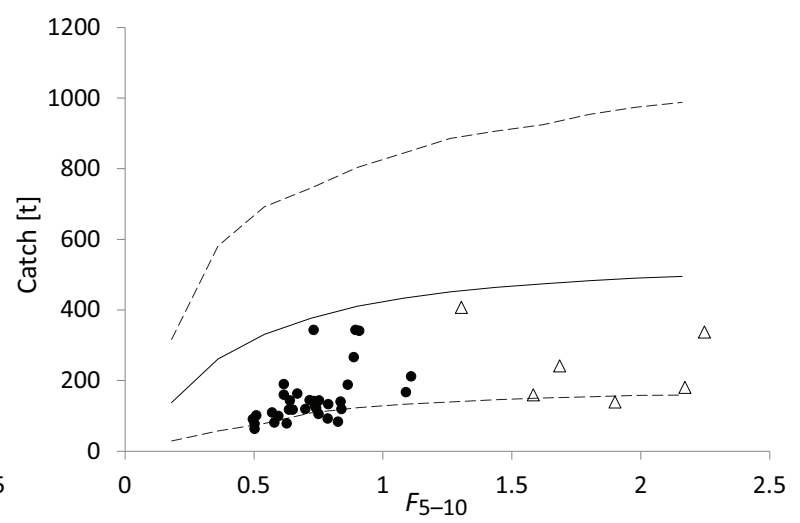

Fig. 5. Selected population characteristics of the Pärnu Bay pikepearch (Sander lucioperca): Spawning stock biomass (left) and catch (right) in equilibrium with different levels of fishing mortality at "future" climate conditions; Lines show average simulated SSB and catch (continuous), with 5\% and 95\% percentiles (dashed); Markers denote observed SSB and catches (Eero 2004) with no (circles) and significant (triangles) catch of immature fish; $F_{5-10}=$ average fishing mortality age 5-10

\footnotetext{
* Laur K., Ojaveer H., Simm M., Klais R. Multidecadal dynamics of goby larvae Pomatoschistus spp. in response to environmental variability in a shallow temperate bay. Submitted to Estuarine, Coastal and Shelf Science.
} 
should be calculated taking into account the natural factors determining the strength of pikeperch year classes, i.e. temperature conditions during spawning and the first wintering period. The clear emphasis on reducing the catch of undersized fish is based on the past experience in managing the stock, when after high fishing pressure on immature fish not even a complete closure of the fishery was sufficient to recover the stock. Our scenarios indicate that the pikeperch stock can sustain catches of $140 \mathrm{t} \cdot$ year $^{-1}$ at significant harvest of immature fish, which is only a decrease by $14 \%$ compared to the maximum catch at harvesting only mature fish. However, without restricting the catch of immature individuals the equilibrium fishing mortality is very low ( 0.54 compared to 0.9 at enforcing the legal size limit, see Table 3), making the stock very sensitive to overfishing. The models constructed quantified the relation between environmental conditions and sustainable catch and it was decided that the contacts between the participating organizations for gradual approximation of the management of the stock to the sustainable optimum stage should be continued in the future.

\section{CONCLUSIONS}

Pikeperch acts as a "biomeliorator" for the Pärnu Bay fishery, roughly doubling the revenues generated from fishing the amount of herring needed to sustain the pikeperch population. Our analysis indicates that the mortality of immature pikeperch must be reduced considerably to achieve catches at the maximum sustainable yield of the stock. Since recruitment depends in a complex way on climate conditions and prey abundance, flexible adaptive methods should be used to calculate the yearly allowable catch. For the implementation of an optimum strategy for the sustainable management of the pikeperch stock, collaboration between the scientists, fishermen's organizations, management bodies and ministry administrators should be continuous.

\section{ACKNOWLEDGEMENTS}

This work was funded by the SPICOSA project (EU FP 6) and received additional support from the Estonian Ministry of Education and Research (grant SF0180005s10), the Estonian Science Foundation (grant 8747) and the European Regional Fund (grant 3.2.0802.11-0029). The authors would like to thank the entire SPICOSA project team, in particular Ragnar Elmgren, Tom Hopkins, and Denis Bailly for their suggestions to the text, and Margit Eero for providing the pikeperch data. We also would like to thank both anonymous reviewers for their careful work.

\section{REFERENCES}

Akaike H. 1974. A new look at the statistical model identification. IEE Transactions on Automatic Control 19 (6): 716-723. DOI: 10.1109/TAC.1974.1100705

Andrews J.M., Blythe S.P., Gurney W.S.C. 2004. Stability analysis of a continuous age-structured model with specific reference to North Sea cod. Journal of Biological Systems 12 (3): 249-260. DOI: 10.1142/S0218339004001191
Anonymous 1996. Third periodic assessment of the state of the Baltic Sea 1989 - 1993. Background Document. HELCOM

Anonymous 2002. Fourth periodic assessment of the state of the marine environment in the Baltic Sea area, 1994-1998. HELCOM.

Arula T., Kotta J., Lankov A., Simm M., Põlme S. 2012. Diet composition and feeding activity of larval spring-spawning herring: Importance of environmental variability. Journal of Sea Research 68: 33-40. DOI: 10.1016/j.seares.2011.12.003

Berzinsh V. 1995. Hydrological regime. Pp. 7-31. In: Ojaveer E. (ed.) Ecosystem of the Gulf of Riga between 1920 and 1990. Vol. 5. Estonian Academy Publishers, Tallinn, Estonia.

Bjørnstad O.N., Fromentin J.-M., Stenseth N.C., Gjøsæter J. 1999. Cycles and trends in cod populations. Proceedings of the National Academy of Sciences of the United States of America 96 (9): 5066-5071. DOI: 10.1073/pnas.96.9.5066

Chen Q.X., Chan K.S., Lekve K., Torstensen E., Gjøsæter J., Ottersen G., Stenseth N.C. 2005. Population dynamics of cod Gadus morhua in the North Sea region: Biological density-dependent and climatic density-independent effects. Marine Ecology-Progress Series 302: 219-232. DOI: 10.3354/meps302219

Daskalov G. 1999. Relating fish recruitment to stock biomass and physical environment in the Black Sea using generalized additive models. Fisheries Research 41 (1): 1-23. DOI: 10.1016/S0165-7836(99)00006-5

Eero M. 2004. Consequences of management of pikeperch (Stizostedion lucioperca L.) stock in Pärnu Bay (Baltic Sea) under two different economic regimes, 1960-1999. Fisheries Research 68 (1-3): 1-7. DOI: 10.1016/ j.fishres.2004.03.002

Erm V. 1981a. Koha. [Pikeperch.] Valgus, Tallinn, Estonia. [In Estonian.]

Erm V. 1981b. Populâcionnye parametry i ocenka stepeni èkspluatacii zapasov sudaka v Pârnuskoj buhte. [Population parameters and estimation of the exploitation rate of pikeperch in Pärnu Bay.] Rybohozâjstviennye issledovaniâ v bassejne Baltijskogo morâ, Riga 16: 46-63.

Erm V., Vaino V., Saat T. 2003. Pikeperch, Sander lucioperca-Fishes of Estonia. Pp. 296-306. In: Ojaveer E., Pihu E., Saat T. (eds.) Fishes of Estonia. Estonian Academy, Tallinn, Estonia.

Fiksen Ø., Slotte A. 2002. Stock-environment recruitment models for Norwegian spring spawning herring (Clupea harengus). Canadian Journal of Fisheries and Aquatic Sciences 59 (2): 211-217. DOI: $10.1139 / \mathrm{f02-002}$

Frankiewicz P., Dabrowski K., Martyniak A., Zalewski M. 1999. Cannibalism as a regulatory force of pikeperch, Stizostedion lucioperca (L.), population dynamics in the lowland Sulejow reservoir (Central Poland). Hydrobiologia 408-409 (0): 47-55. DOI: 10.1023/A:1017001803791

Garcia X.-F., Diekmann M., Brämick U., Lemcke R., Mehner T. 2006. Correlations between type-indicator fish species and lake productivity in German lowland lakes. Journal of Fish Biology 68 (4): 1144-1157. DOI: 10.1111/j.0022-1112.2006.01009.x

Gröger J.P., Winkler H., Rountree R.A. 2007. Population dynamics of pikeperch (Sander lucioperca) and its linkage 
to fishery driven and climatic influences in a southern Baltic lagoon of the Darss-Zingst Bodden chain. Fisheries Research 84 (2): 189-201. DOI: 10.1016/j.fishres. 2006.10.018

Guthrie D.M. 1986. Role of vision in fish behaviour. Pp. 75-113. In: Pitcher T.J. (ed.) The behaviour of teleost fishes. Croom Helm, Beckenham, Kent, UK. DOI: 10.1007/9781-4684-8261-4 4

Haddon M. 2011. Modelling and quantitative methods in fisheries. 2nd edn. CRC Press, Boca Raton, FL, USA.

Håkanson L. 1999. Error propagations in step-by-step predictions: examples for environmental management using regression models for lake ecosystems. Environmental Modelling and Software 14 (1): 49-58. DOI: 10.1016/S1364-8152(98)00022-X

Håkanson L. 2003. Propagation and analysis of uncertainty in ecosystem models. Pp. 139-167. In: Canham C.D., Cole J.J., Lauenroth W.K. (eds.) Models in ecosystem science. Princeton University Press, Princeton, New Jersey, USA.

Hastie T., Tibshirani R. 1986. Generalized additive models. Statistical Science 1 (3): 297-318. DOI: 10.1214/ ss/1177013604

Higgins K., Hastings A., Sarvela J.N., Botsford L.W. 1997. Stochastic dynamics and deterministic skeletons: Population behavior of Dungeness crab. Science 276 (5317): 1431-1435. DOI: 10.1126/science.276.5317.1431

Kangur K., Park Y.-S., Kangur A., Kangur P., Lek S. 2007. Patterning long-term changes of fish community in large shallow Lake Peipsi. Ecological Modelling 203(1-2): 34-44. DOI: 10.1016/j.ecolmodel.2006.03.039

Keyl F., Wolff M. 2008. Environmental variability and fisheries: what can models do? Reviews in Fish Biology and Fisheries 18 (3): 273-299. DOI: 10.1007/s11160-007-9075-5

Kotta J., Kotta I., Simm M., Põllupüü M. 2009. Separate and interactive effects of eutrophication and climate variables on the ecosystem elements of the Gulf of Riga. Estuarine, Coastal and Shelf Science 84 (4): 509-518. DOI: 10.1016/j.ecss.2009.07.014

Lappalainen J., Dörner H., Wysujack K. 2003. Reproduction biology of pikeperch (Sander lucioperca (L.)) - a review. Ecology of Freshwater Fish 12 (2): 95-106. DOI: 10.1034/j.1600-0633.2003.00005.x

Lappalainen J., Erm V., Kjellman J., Lehtonen H. 2000. Size-dependent winter mortality of age- 0 pikeperch (Stizostedion lucioperca) in Pärnu Bay, the Baltic Sea. Canadian Journal of Fisheries and Aquatic Sciences 57 (2): 451-458. DOI: 10.1139/f99-270

Lappalainen J., Milardi M., Nyberg K., Venäläinen A. 2009. Effects of water temperature on year-class strengths and growth patterns of pikeperch (Sander lucioperca (L.)) in the brackish Baltic Sea. Aquatic Ecology 43 (1): 181-191. DOI: 10.1007/s10452-007-9150-y

Lappalainen J., Olin M., Vinni M. 2006. Pikeperch cannibalism: effects of abundance, size and condition. Annales Zoologici Fennici 43 (1): 35-44.

Lappalainen A., Soderkultalahti P., Wiik T. 2002. Changes in the commercial fishery for pikeperch (Stizostedion lucioperca) on the Finnish coast from 1980 to 1999-Consequences of environmental and economic factors. Archive of Fishery and Marine Research 49 (3): 199-212.

Laur K., Arula T., Ojaveer H. 2009. Long-term dynamics of early life stages of gobies (Pomatoschistus spp.) in Pärnu Bay (Gulf of Riga). Pp. 231-231. In: Abstract book: 7th Baltic Sea Science Congress 2009; 17-21 August 2009, Tallinn University of Technology, Estonia.

Lehtonen H., Hansson S., Winkler H. 1996. Biology and exploitation of pikeperch, Stizostedion lucioperca (L), in the Baltic Sea area. Annales Zoologici Fennici 33 (3-4): 525-535.

MacKenzie B.R., Gislason H., Möllmann C., Köster F.W. 2007. Impact of 21 st century climate change on the Baltic Sea fish community and fisheries. Global Change Biology 13 (7): 1348-1367. DOI: 10.1111/j.1365-2486.2007.01369.x

Marjomäki T.J. 2004. Analysis of the spawning stockRecruitment relationship of vendace (Coregonus albula (L.)) with evaluation of alternative models, additional variables, biases and errors. Ecology of Freshwater Fish 13 (1): 46-60. DOI: 10.1111/j.0906-6691.2004.00041.x

Megrey B.A., Lee Y.-W., Macklin S.A. 2005. Comparative analysis of statistical tools to identify recruitmentEnvironment relationships and forecast recruitment strength. ICES Journal of Marine Science 62 (7): 1256-1269. DOI: 10.1016/j.icesjms.2005.05.018

Nehring D., Schulz S., Rechlin O. 1989. Eutrophication and fishery resources in the Baltic. Journal du Conseil International pour l'Exploration de la Mer 190: 198-205.

Ojaveer E., Arula T., Lankov A., Shpilev H. 2011. Impact of environmental deviations on the larval and year-class abundances in the spring spawning herring (Clupea harengus membras L.) of the Gulf of Riga (Baltic Sea) in 1947-2004. Fisheries Research 107 (1-3): 159-168. DOI: 10.1016/j.fishres.2010.11.001

Ojaveer H., Lankov A., Lumberg A., Turovski A. 1997. Forage fishes in the brackish Gulf of Riga ecosystem (Baltic Sea). Pp. 293-309. In: Forage fishes in marine ecosystems. Proceedings of the International Symposium on the Role of Forage Fishes in Marine Ecosystems. Anchorage, Alaska, USA, November 13-16, 1996. Alaska Sea Grant College Program, University of Alaska Fairbanks.

Paavel B., Arst H., Metsamaa L., Toming K., Reinart A. 2011. Optical investigations of CDOM-rich coastal waters in Pärnu Bay. Estonian Journal of Earth Sciences 60 (2): 102-112. DOI: 10.3176/earth.2011.2.04

Sandström A., Karås P. 2002. Effects of eutrophication on young-of-the-year freshwater fish communities in coastal areas of the Baltic. Environmental Biology of Fishes 63 (1): 89-101. DOI: 10.1023/A:1013828304074

Sprugel D.G. 1983. Correcting for bias in log-transformed allometric equations. Ecology 64 (1): 209-210. DOI: $10.2307 / 1937343$

Tomczak M.T., Müller-Karulis B., Järv L., Kotta J., Martin G., Minde A., Põllumäe A., Razinkovas A., Strake S., Bucas M., Blenckner T. 2009. Analysis of trophic networks and carbon flows in south-eastern Baltic coastal ecosystems. Progress in Oceanography 81 (1-4): 111-131. DOI: 10.1016/j.pocean.2009.04.017 
Utne-Palm A.C. 2002. Visual feeding of fish in a turbid environment: Physical and behavioural aspects. Marine and Freshwater Behaviour and Physiology 35 (1-2): 111-128. DOI: $10.1080 / 10236240290025644$

Vetemaa M., Eero M., Hannesson R. 2002. The Estonian fisheries: from the Soviet system to ITQs and quota auctions. Marine Policy 26 (2): 95-102. DOI: 10.1016/S0308597X(01)00040-9

Vetemaa M., Eschbaum R., Aps R., Saat T. 2000. Collapse of political and economical system as a cause for instability in fisheries sector: an Estonian case. Pp. 1-9. In: Proceedings of the IIFET 2000 International Conference Microbehaviour and Macroresults; 10-14 July 2000, Oregon State University, Corvallis, OR, USA.

Vetemaa M., Eschbaum R., Saat. T. 2006. The transition from the Soviet system to a market economy as a cause of insta- bility in the Estonian coastal fisheries sector. Marine Policy 30 (6): 635-640. DOI: 10.1016/j.marpol.2005.08.001

Winkler H.M. 1989. The role of predators in fish communities in shallow coastal waters of the southeast Baltic. Rapports et Proces-verbaux des Réunions. Conseil International pour l'Exploration de la Mer 190: 125-132.

Wood S.R. 2006. Generalized additive models. An introduction with R. Chapman and Hall/CRC, Texts in Statistical Science, Boca Ration, FL, USA.

Received: 29 October 2012 Accepted: 29 May 2013 Published electronically: 30 June 2013 